\title{
Assessment of the age of bruise by their healing
}

\author{
Manish Nigam¹, Divyesh Saxena ${ }^{2, *}$, Pradeep Kumar Mishra ${ }^{3}$, Jitendra Singh Tomar ${ }^{4}$ \\ ${ }^{1}$ Professor and Head, Dept. of Forensic Medicine \& Toxicology, Government Autonomous Medical College, Vidisha, Madhya \\ Pradesh, ${ }^{2}$ Senior Resident, Dept. of Forensic Medicine \& Toxicology, All India Institute of Medical Sciences, Rishikesh, \\ Uttarakhand ${ }^{3}$ Professor, Dept. of Forensic Medicine \& Toxicology, Government Medical College, Ratlam, Madhya Pradesh, \\ ${ }^{4}$ Assistant Professor, Dept. of Forensic Medicine \& Toxicology, M.G.M. College, Indore, Madhya Pradesh, India
}

*Corresponding Author:

Email: drdivyesh.saxena@gmail.com

\begin{abstract}
Any investigative agency should have the knowledge to make out when the trauma event has occurred. Dating of bruise is of paramount importance to opine on the time of its infliction. Age of the bruise can be recorded by observation of colors during the process of healing. The present study was carried out on 50 individuals who were brought to the emergency/OPD/IPD/cases or for post-mortem examination. Results of the present study were compared with published literature. 100\% individuals showed bright red color within 12 hrs. Bluish colors appeared in $48 \%$ patients between 24 to 48 hours. The bluish-black color was developed on the 3 rd day in $50 \%$ of patients. $38 \%$ patients manifested brown color of the bruise with green periphery on the 5 th day. Observations of the present study were comparable but varied erratically with the persistent color changes stated in the literature.
\end{abstract}

Keywords: Age, Assessment, Bruise, Healing, Contusion.

\section{Introduction}

Any injury as a result of accident or assault occurs in the form of contusion. Assessment of such injuries form an important aspect of forensic medicine. ${ }^{1}$ They have significant consequences in medico-legal cases. ${ }^{2}$ Contusion can be defined as localized discoloration of skin caused due to extravasation of blood beneath the epidermis following injury due to blunt impact. ${ }^{3}$ Sir Bernard stated that "Bruises are much neglected branch of injuries." Present scenario being changed, it has now become the prime responsibility of forensic expert to carefully record the details of injury on the body. Healing of a contusion undergoes stages of color changes. Such changes may be attributed to damage to subcutaneous vessels and breakdown of hemoglobin. ${ }^{5}$ Contusion is an anti-mortem event. ${ }^{6}$ Bruises can be observed in association with abrasion or laceration.

Bruises varies from size of a pinhead to large collection of blood in the tissues. Greater is the force of violence, the more extensive will be the bruise. Certain disorders like coagulation disorder, hypertension or drugs like steroids may affect the extent of visible bruise. ${ }^{7,8}$ Degree of violence can be determined from the size. Various studies have been carried out to estimate and analyze the age process of contusion but there has been the difference of opinion at times.

However no recent detailed Indian study is available on this aspect, hence this study has been conducted to ascertain the age of injury by comparing the color changes with that of the time of infliction of injury.

\section{Materials and Methods}

It is an descriptive observation study carried out on 50 individuals who were brought to the emergency department of Sri Aurobindo Institute of medical sciences. This study was commenced after getting approval by institutional ethical committee. Informed consent was taken from patients. Detailed history was taken about the infliction of injuries. Treatment case sheets were reviewed as and when required. Injuries were examined and their time of infliction was recorded. Repeated subsequent examination of each case was carried out at time of first inspection, then between 12-24 hours, $2^{\text {nd }}$ day, $3^{\text {rd }}$ day, $4^{\text {th }}$ day, $5^{\text {th }}$ and continuing it on every day till time of healing was reached to record various colour changes (Table 1) and conclusion was drawn.

\section{Table 1: Healing of contusion}

\begin{tabular}{|c|c|}
\hline Contusion & Red \\
\cline { 2 - 2 } & Bluish (Fig. 1) \\
\cline { 2 - 2 } & Bluish black (Fig. 2) \\
\cline { 2 - 2 } & $\begin{array}{c}\text { Brown in the centre with green } \\
\text { periphery (Fig. 3) }\end{array}$ \\
\cline { 2 - 2 } & Greenish-Yellow (Fig. 4) \\
\cline { 2 - 2 } & Yellow (Fig. 5) \\
\hline & Normal \\
\hline
\end{tabular}

\section{Results}

50 participants were included in the present study of different age group ranging from 18 to 60 years (Table 5). Among these 32 were males and 18 females. In our study bright red color of contusion was noted within 12 hours of injury in all patients (Table 3). In $48 \%$ of patients color changed to bluish shade within 24-48 hours (Table 3). Healing reached to other stage of bluish black contusion that was seen on day 3 in 50\% patients (Table 3). In one individual it was seen on day 
6. Brown color of bruise with green periphery was seen on $5^{\text {th }}$ day in $38 \%$ of patients (Table 3 ). In $2 \%$ patients it was seen on $9^{\text {th }}$ day. Much variations were seen in later stages of healing of a bruise. In $28 \%$ and $24 \%$ of patients greenish yellow color of bruise was seen on day 7 and day 8 respectively (Table 4 ). In others it was seen on $10^{\text {th }}-11^{\text {th }}$ day. It turned to yellow color in $9^{\text {th }}$ $11^{\text {th }}$ day (Table 4). Normal skin color was restored to normal on approx $12^{\text {th }}$ day in $30 \%$ patients.

Table 2: observational results of Indian authors

\begin{tabular}{|l|c|c|c|c|}
\hline Color change & N.G. Rao & K. Vij & K.S.N Reddy $^{\mathbf{1 0}}$ & J.P Modi $^{\mathbf{1 8}}$ \\
\hline Bright red & $\begin{array}{c}\text { Freshly } \\
\text { produced }\end{array}$ & Fresh & Fresh & $1^{\text {st }}$ day \\
\hline Bluish & $\begin{array}{c}\text { Few hours- } \\
\text { day }\end{array}$ & Few hours & Few hours $-3^{\text {rd }}$ day & $2^{\text {nd }}-3^{\text {rd }}$ day \\
\hline Bluish purple & - & $2^{\text {nd }}$ day & - & - \\
\hline Bluish black/brown & $4^{\text {th }}$ day & $3^{\text {rd }}-4^{\text {th }}$ day & $4^{\text {th }}$ day & $3^{\text {rd }}-4^{\text {th }}$ day \\
\hline Greenish & $4^{\text {th }}-5^{\text {th }}$ days & $5^{\text {th }}-6^{\text {th }}$ day & $5^{\text {th }}-6^{\text {th }}$ day & $5^{\text {th }}-6^{\text {th }}$ day \\
\hline Yellow & $7^{\text {th }}-12^{\text {th }}$ days & $7^{\text {th }}-10^{\text {th }}$ & $7^{\text {th }}-12^{\text {th }}$ days & $7^{\text {th }}-12^{\text {th }}$ day \\
\hline Normal & 2 weeks & 2 weeks & 2 weeks & 2 weeks \\
\hline
\end{tabular}

Table 3: Colour changes of contusion in initial stages of healing

\begin{tabular}{|c|c|c|c|}
\hline Condition & Time & $\begin{array}{c}\text { Total } \\
(\mathbf{N}=\mathbf{5 0})\end{array}$ & \\
\hline & & No. & Percentage \\
\hline Red & $0-12$ hours & 50 & 100 \\
\hline \multirow{3}{*}{ Bluish } & $12-24$ hours & 24 & 48 \\
\hline & 24-48 hours & 24 & 48 \\
\hline & Day - 3 & 2 & 4 \\
\hline \multirow{4}{*}{ Bluish-Black } & Day - 3 & 25 & 50 \\
\hline & Day - 4 & 21 & 42 \\
\hline & Day - 5 & 3 & 6 \\
\hline & Day - 6 & 1 & 2 \\
\hline \multirow{6}{*}{ Brown in the center with green periphery } & Day - 4 & 5 & 10 \\
\hline & Day - 5 & 19 & 38 \\
\hline & Day - 6 & 16 & 32 \\
\hline & Day -7 & 7 & 14 \\
\hline & Day -8 & 2 & 4 \\
\hline & Day - 9 & 1 & 2 \\
\hline
\end{tabular}

Table 4: Colour changes in contusion in later stages

\begin{tabular}{|c|c|c|c|}
\hline \multirow[t]{2}{*}{ Condition } & \multirow[t]{2}{*}{ Time } & \multicolumn{2}{|c|}{$\begin{array}{c}\text { Total } \\
(\mathrm{N}=50)\end{array}$} \\
\hline & & No. & Percentage \\
\hline \multirow[t]{7}{*}{ Greenish-yellow } & Day-6 & 4 & 8 \\
\hline & Day-7 & 12 & 24 \\
\hline & Day-8 & 14 & 28 \\
\hline & Day-9 & 10 & 20 \\
\hline & Day-10 & 6 & 12 \\
\hline & Day-11 & 2 & 4 \\
\hline & Day-12 & 2 & 4 \\
\hline \multirow[t]{7}{*}{ Yellow } & Day-8 & 6 & 12 \\
\hline & Day-9 & 10 & 20 \\
\hline & Day-10 & 14 & 28 \\
\hline & Day-11 & 10 & 20 \\
\hline & Day-12 & 7 & 14 \\
\hline & Day-13 & 2 & 4 \\
\hline & Day-14 & 1 & 2 \\
\hline
\end{tabular}




\begin{tabular}{|l|c|c|c|}
\hline Normal & Day-10 & 6 & 12 \\
\cline { 2 - 4 } & Day-11 & 9 & 18 \\
\cline { 2 - 4 } & Day-12 & 15 & 30 \\
\cline { 2 - 4 } & Day-13 & 8 & 16 \\
\cline { 2 - 4 } & Day-14 & 9 & 18 \\
\cline { 2 - 4 } & Day-15 & 2 & 4 \\
\cline { 2 - 4 } & Day-16 & 1 & 2 \\
\hline
\end{tabular}

Table 5: distribution of patient according to the age

\begin{tabular}{|l|c|c|c|}
\hline \multirow{2}{*}{ S. No. } & \multirow{2}{*}{ Age in years } & \multicolumn{2}{|c|}{$\begin{array}{c}\text { Total } \\
(\mathbf{N}=50)\end{array}$} \\
\cline { 3 - 4 } & & No. of cases & Percentage \\
\hline 1. & $18-20$ & 6 & $12 \%$ \\
\hline 2. & $21-30$ & 26 & $52 \%$ \\
\hline 3. & $31-40$ & 13 & $26 \%$ \\
\hline 4. & $41-50$ & 5 & $10 \%$ \\
\hline 5. & $51-60$ & 0 & $0 \%$ \\
\hline
\end{tabular}

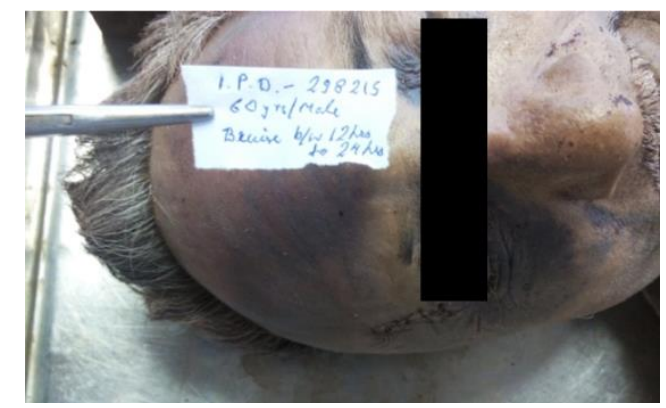

Fig. 1: Contusion - Bluish colour

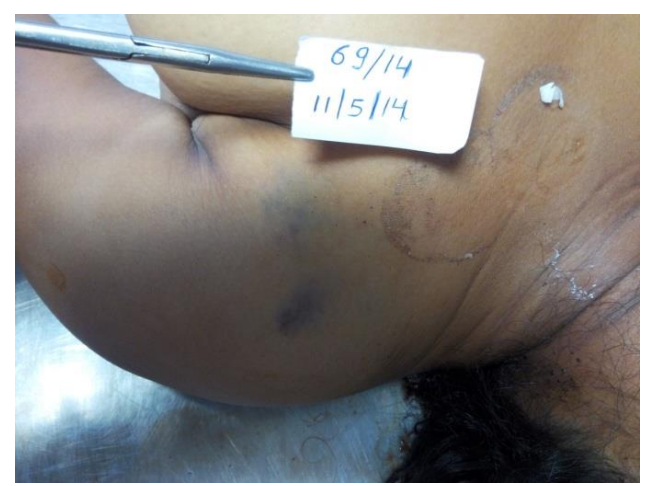

Fig. 2: Contusion - Bluish-black colour

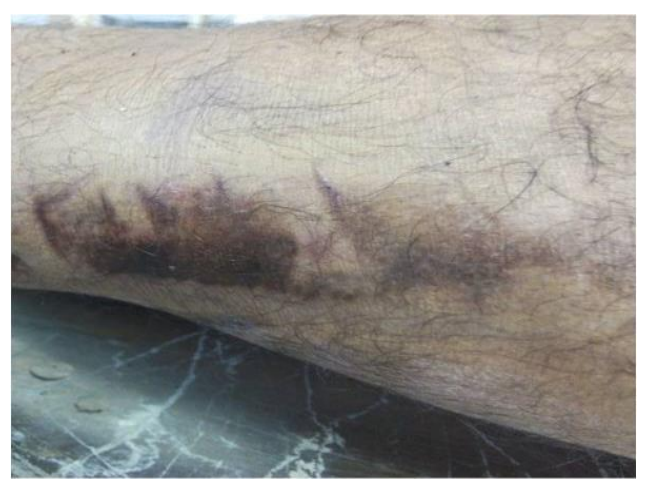

Fig. 3: Contusion - Brown in centre with green in periphery

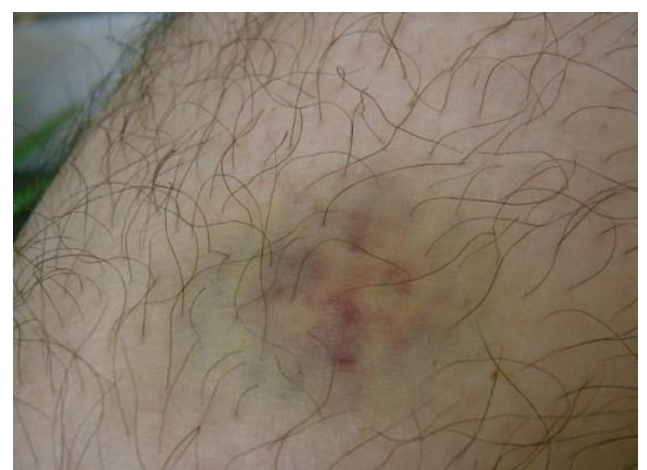

Fig. 4: Contusion Greenish- yellow in colour

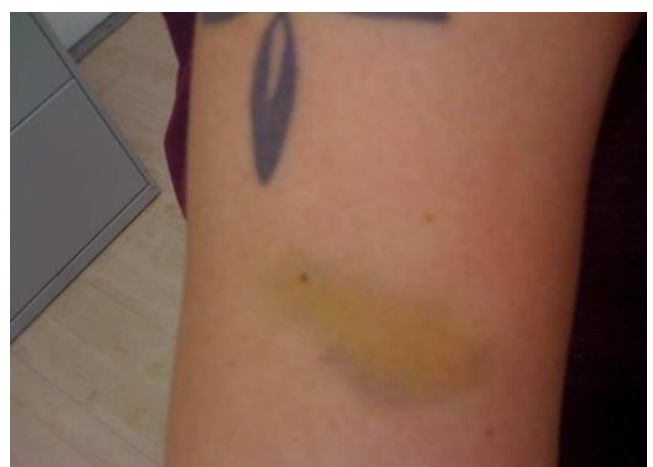

Fig. 5: Contusion yellow in colour

\section{Discussion}

Being medico-legally important various methods have been described for age estimation of bruise. They include visual assessment, biochemical, histological and electrophysiological methods. ${ }^{5}$ In this study we have considered visual assessment method. Color changes occur because of breakdown of hemoglobin of extravasated blood in subcutaneous plane. Immediately after injury there is blood collected in the tissue planes. As a result inflammatory response is initiated. ${ }^{9}$ Red blood cells are phagocytosed by macrophages and hemoglobin is degraded. This is depicted as color 
change of skin depending on depth within the skin as hemoglobin undergoes biochemical oxidative changes. ${ }^{10}$ Hemoglobin is acted upon by heme oxygenase to produce biliverdin (producing green color). Released iron binds to ferritin to produce hemosiderin Biliverdin is then metabolized to bilirubin (yellow). ${ }^{11}$

There are multiple factors that account for the variability in bruise appearance. There can be victim related factors like percentage of body fat, skin color, age and sex or there can be factors related to occurrence of injury like site, force of impact and type of weapon used. ${ }^{13}$ There may also be a variability in subjective perception of colors. This was proved in the study conducted by Munang et al in 2002. ${ }^{12}$

In our study, aging of bruise was recorded by observation of colors during the process of healing. Results of the present studies are compared with scientific literature categorizing colors of contusion into red, bluish, bluish-black, brownish in the centre with green in periphery, greenish-yellow, yellow \& normal. (Table 2)

$52 \%$ cases in our study were observed in age group of 21-30 yrs. Amongst these 64\% were males and were more commonly involved as regards to sex, bruise appear earlier in females as compared to males. ${ }^{14}$

There was no variations in occurrence of red color of bruise when compared to other similar studies. However langois et al showed presence of red color in bruise from $0 \mathrm{hrs}$ to 20 days. $^{5}$ Consistently similar results were obtained with other studies in appearance of bluish color. This changed to bluish black color on $3^{\text {rd }}$ day in $50 \%$ patients. This was not similar to the study of Polson and Gee where they noticed bluish black color in less than 24 hrs. ${ }^{15}$ Bruise reached to another stage of healing with green periphery and brown centre on $5^{\text {th }}-6^{\text {th }}$ day in $38 \%$ patients and outcome was similar to other studies. Greenish yellow color as a result of deposition of bilirubin was seen on day 7-day 9 and results were consistent to other studies carried out by Indian authors. This turned to completely yellow colored bruise from $7^{\text {th }}$ to $10^{\text {th }}$ day. This was in accordance to other study except the study of Polson \& Gee where it occurred on $14^{\text {th }}$ day. ${ }^{15}$ Tissues resumed back to normal on $12^{\text {th }}$ to $15^{\text {th }}$ day.

\section{Conclusion}

From the above summary, we conclude that initial stages of healing were more consistent in time frame. However later stages of healing were observed to be more erratic offering a dogmatic opinion. It was observed during study that number of variables such as size of injury, effect of force, location on the body, age of subject, disease condition of patient have affected healing process.

\section{References}

1. Bohnert M, Baumgartner R, Pollak S. Spectrophotometric evaluation of the colour of intra-and subcutaneous bruises. International journal of legal medicine. $2000 \mathrm{Oct}$ $1 ; 113(6): 343-8$.

2. Trujillo O, Vanezis P, Cermignani M. Photometric assessment of skin colour and lightness using a tristimulus colorimeter: reliability of inter and intrainvestigator observations in healthy adult volunteers. Forensic science international. 1996 Jul 31;81(1):1-0.

3. Capper $\mathrm{C}$. The language of forensic medicine: the meaning of some terms employed. Medicine, Science and the Law. 2001 Jul;41(3):256-9.

4. Spilsbury B. The medico-legal significance of bruises. Medicao-Legal and Criminological Review. 1939 Jul;7(3):215-27.

5. Langlois NE, Gresham GA. The ageing of bruises: a review and study of the colour changes with time. Forensic Science International. 1991 Sep 1;50(2):227-38.

6. Vanezis P. Interpretation of injuries, lecture given to the royal military police crime scene investigation course. Portsmouth; 2008

7. Smith H. Glaister's medical jurisprudence and toxicology. Rentoul E, editor. Edinburgh: Livingstone; 1973.

8. Lovell RR, Scott GB, Hudson B, Osborne JA. The effects of cortisone and adrenocorticotrophic hormone on dispersion of bruises in the skin. British journal of experimental pathology. 1953 Oct;34(5):535.

9. Hughes VK, Ellis PS, Burt T, Langlois NE. The practical application of reflectance spectrophotometry for the demonstration of haemoglobin and its degradation in bruises. Journal of clinical pathology. $2004 \mathrm{Apr}$ 1;57(4):355-9.

10. Kollias N. The physical basis of skin color and its evaluation. Clinics in dermatology. 1995 Jul 1;13(4):3617.

11. Pilling ML, Vanezis P, Perrett D, Johnston A. Visual assessment of the timing of bruising by forensic experts. Journal of forensic and legal medicine. $2010 \mathrm{Apr}$ 1;17(3):143-9.

12. Munang LA, Leonard PA, Mok JY. Lack of agreement on colour description between clinicians examining childhood bruising. Journal of clinical forensic medicine. 2002 Dec 1;9(4):171-4.

13. Knight B, Saukko P. The pathology of wounds. Forensic pathology. 1996;3:136-73.

14. Nandy A. Principles of Forensic Medicine. $2^{\text {nd }}$ ed. Calcutta: New Central Book Agency (P) Ltd; 2004.

15. Polson CJ and Gee DJ. The Essentials of Forensic Medicine. $3^{\text {rd }}$ edn: Oxford. Pergamon press, 1973.

16. Rao NG. Text book of forensic medicine and toxicology. $2^{\text {nd }}$ ed. New Delhi: Jaypee Publication; 2010.

17. Vij K. Textbook of Forensic Medicine and Toxicology Principles and Practice. $3^{\text {rd }}$ ed. New Delhi. Reed Elsevier India Pvt Ltd.; 2005.

18. Reddy KSN. The essentials of forensic medicine and toxicology. $33^{\text {rd }}$ ed. Hyderabad. Jaypee publishers; 2014

19. Modi JP. Modi's Medical Jurisprudence \& Toxicology. $22^{\text {nd }}$ ed. New Delhi: Tripathi Publication; 2002. 